\title{
Effects of municipal waste compost and nitrogen fertilizer on growth and mineral composition of tomato
}

\author{
Majid Rajaie $^{1}$ Amir Reza Tavakoly ${ }^{1}$
}

Received: 19 January 2016/ Accepted: 19 October 2016/Published online: 25 October 2016

(c) The Author(s) 2016. This article is published with open access at Springerlink.com

\begin{abstract}
Purpose Since simultaneous use of organic and mineral fertilizers on the basis of their chemical compositions can lead to better plant growth and soil fertility, the roles of municipal waste compost (MWC) and nitrogen (N) fertilizer on growth and mineral composition of tomato and some soil properties were evaluated under greenhouse condition.

Methods Treatments involved four MWC rates $(0,1,2$, and $4 \%$ on the basis of soil dry weight) and four $\mathrm{N}$ levels $\left(0,50,100\right.$, and $200 \mathrm{mg} \mathrm{kg}^{-1}$ soil). Red cloud variety of tomato was sown in treated soils and 9 weeks later dried plant shoots and soil sub-samples were subjected to analysis.

Results Combined use of MWC and N led to better growth of tomato than sole application of either MWC or N fertilizer. Plant concentration and/or uptake of nitrogen, phosphorus, zinc, copper, iron, and manganese were increased by both MWC and N. The beneficial effect of MWC on nutrients uptake was more pronounced with $\mathrm{N}$ addition. Plant and soil concentrations of cadmium and lead were under the detection limit of atomic absorption spectrophotometer. Soluble salts, organic matter, sodium, chloride and DTPA-extractable zinc, copper, iron, and manganese in the soil were effectively increased with addition of MWC.
\end{abstract}

Majid Rajaie

rajaie.majid@yahoo.com

Amir Reza Tavakoly

Tava1347@yahoo.com

1 Darab Research Station, Research Center for Agriculture and Education and Natural Resources of Fars Province, Shiraz, Iran
Conclusions Due to high soil $\mathrm{pH}$ and calcium carbonate equivalent (CCE) values of the calcareous soil, MWC heavy metals had no hazardous effect on tomato and even played a nutritional role. The most important problem raised from MWC application was the accumulation of soluble salts in the soil which must be monitored when making repeated application of MWC over an extended period of time.

Keywords Municipal waste compost $\cdot$ Nitrogen $\cdot$ Alkaline condition $\cdot$ Tomato $\cdot$ Heavy metals $\cdot$ Soil properties

\section{Introduction}

Generally, most agricultural soils of Iran have low content of organic matter (OM) and suffer from poor physical conditions (Havaee et al. 2014). On the other hand, daily production of large quantities of solid organic wastes causes serious disposal problems, environmental pollution, and possible health risks. Using a good strategy such as composting process, solid wastes can be converted into useful products for improvement of soils properties (Hashemimajd et al. 2004; Sohrabi Yourtchi et al. 2013). Soil disposal of municipal waste compost (MWC) is an attractive practical procedure reducing the waste disposal problems in large cities. Compost can be considered as a valuable source of nitrogen $(\mathrm{N})$, phosphorous $(\mathrm{P})$, essential trace elements, and OM that well improves soil physical properties and plant nutritional status (Bertoldi et al. 1996; Zinati et al. 2004; Kabirinejad and Hoodaji 2012). The two major drawbacks encountered from application of compost to soils are the accumulation of an excess amount of soluble salts in treated soils and the potential toxicity of certain trace elements to plants (Maftoun et al. 2004). 
Trace amounts of some elements such as copper $(\mathrm{Cu})$, iron $(\mathrm{Fe})$, manganese $(\mathrm{Mn})$, and zinc $(\mathrm{Zn})$ are essential micronutrients for plants, animals and microorganisms, but when applied in excessive amounts they may depress plant growth and reduce the quality of food materials (Petruzzelli 1996).

The uptake of trace elements from soil by higher plants depends on a variety of intrinsic soil factors such as soil $\mathrm{pH}$ (Basta and Tabatabai 1992), soil type (Eriksson 1989), OM content (McGrath et al. 1988), and composition of soil solution (Bingham et al. 1979). Some of these factors can be easily changed by addition of various materials to soil. Fertilizer application is a significant external factor that can affect the uptake of trace elements under certain circumstances. One of the most important elements in plant nutrition is $\mathrm{N}$ and many researchers have investigated the influence of $\mathrm{N}$ fertilizers on trace elements uptake for a long time. $\mathrm{N}$ fertilizers with acidifying potentiality have the capacity to decrease soil $\mathrm{pH}$ and increase the trace elements uptake by plants. Since decrease in soil $\mathrm{pH}$ by $\mathrm{N}$ fertilizers during the plant cultivation is mainly due to ammonium $\left(\mathrm{NH}_{4}^{+}\right)$uptake by plants and nitrification by microorganisms, fertilizers containing $\mathrm{NH}_{4}^{+}$salts are potentially acidifying and can affect the trace elements uptake by plants (Ohtani et al. 2007). Parvizi et al. (2004) investigated the effect of $\mathrm{N}$ and $\mathrm{Mn}$ on growth, nutrient concentration and chlorophyll meter readings in wheat under greenhouse condition. Their results showed that applied $\mathrm{N}$ levels $\left(0,50,100,200\right.$, and $400 \mathrm{mg} \mathrm{kg}^{-1}$ soil as $\mathrm{NH}_{4} \mathrm{NO}_{3}$ ) increased dry matter yield and the concentration of $\mathrm{N}, \mathrm{Mn}, \mathrm{Fe}, \mathrm{Zn}$, and $\mathrm{Cu}$ in plant shoot. Karimian and Ahangar (1998) reported that $\mathrm{N}$ reduced the antagonistic effect of phosphorus on $\mathrm{Zn}$ and increased plant $\mathrm{Zn}$ concentration. They concluded that such positive effect of $\mathrm{N}$ was probably due to the enhancing effect of $\mathrm{N}$ on root volume and growth. Rodriguez-Ortiz et al. (2006) showed that increase of ammonium nitrate application to soil (50,100, and $150 \mathrm{mg} \mathrm{N} \mathrm{kg}^{-1}$ soil) significantly increased the aboveground accumulation of cadmium $(\mathrm{Cd})$ and lead $(\mathrm{Pb})$ in tobacco during a 50-day experimental period. Eriksson (1990) reported that Cd availability in two soils was increased after the application of acidifying $\mathrm{N}$ fertilizers.

From the other point of view, simultaneous use of organic and mineral fertilizers based on their chemical composition can lead to the improvement of plant yield and the fertility of soil. Most existing studies show positive effects of the combined application of organic amendments and mineral fertilizers on soil fertility by improvement of water and nutrient-holding capacity of the soil, minimizing the leaching losses and maximizing the efficiency of applied nutrient (Amusan et al. 2011; Chivenge et al.
2011). Apart from enhancing crop yield, the practice has a greater beneficial residual effect than the sole use of mineral fertilizer or organic materials (Cela et al. 2011; Demelash et al. 2014).

Since there is limited information on combined use of organic and mineral fertilizers, especially with respect to their adverse or beneficial impacts under alkaline/calcareous conditions of soils in Iran, the present study was initiated to (1) evaluate the combined effects of several rates of MWC and N levels on the growth and mineral composition of greenhouse tomato and (2) determine their impacts on some selected soil properties.

\section{Methods}

A bulk sample was collected from surface horizon $(0-20 \mathrm{~cm})$ of a fine, mixed (calcareous), mesic Typic Calcixerpts soil that was homogenized by plowing. Prior to analysis and potting, the soil was air dried, crushed and passed through a 2-mm sieve. Some physical and chemical characteristics of the soil sample are shown in Table 1. Municipal waste compost (MWC) was obtained from Isfahan Compost Company, air dried, and passed through a 2-mm sieve. Compost analysis was done by standard methods. Elements total concentration was measured as explained below for plant samples and cation and anion concentrations were measured by the procedure suggested by U.S. Salinity Laboratory Staff (1954). Some analytical

Table 1 Physical and chemical properties of the soil

\begin{tabular}{ll}
\hline Soil property & Quantity \\
\hline Sand (\%) & 10 \\
Silt (\%) & 46 \\
Clay (\%) & 44 \\
Texture & Silty clay \\
OM (\%) & 1.02 \\
CCE (\%) & 31 \\
EC $\left(\mathrm{dSm}{ }^{-1}\right)$ & 0.24 \\
CEC (cmol c kg $\left.{ }^{-1}\right)$ & 21 \\
pH (saturated paste) & 8.0 \\
Total N (\%) & 0.07 \\
NaHCO3-extractable P $\left(\mathrm{mg} \mathrm{kg}^{-1}\right)$ & 18.5 \\
DTPA-extractable Fe $\left(\mathrm{mg} \mathrm{kg}^{-1}\right)$ & 2.2 \\
DTPA-extractable $\mathrm{Mn}\left(\mathrm{mg} \mathrm{kg}^{-1}\right)$ & 4.2 \\
DTPA-extractable $\mathrm{Zn}\left(\mathrm{mg} \mathrm{kg}^{-1}\right)$ & 0.72 \\
DTPA-extractable Cu $\left(\mathrm{mg} \mathrm{kg}^{-1}\right)$ & 1.5 \\
\hline
\end{tabular}

$O M$ organic matter, $C C E$ calcium carbonate equivalent, $E C$ electrical conductivity, $C E C$ cation exchange capacity, DTPA diethylene triamine pentaacetic acid 
properties of the MWC are presented in Table 2. Treatments consisted of four levels of MWC $(0,1,2$, and $4 \%$ on the basis of soil dry weight) and four $\mathrm{N}$ rates $(0,50,100$, and $200 \mathrm{mg} \mathrm{kg}^{-1}$ soil as urea) arranged in a factorial manner into a completely randomized design with three replications. Pots were filled with $2 \mathrm{~kg}$ of air-dried soil, thoroughly mixed with uniform amount of phosphorous (20 mg kg${ }^{-1}$ soil as $\mathrm{KH}_{2} \mathrm{PO}_{4}$ ), appropriate amounts of MWC and half of the nitrogen treatments. Ten seeds of tomato (Lycopersicon esculentum L.), Red cloud var., were sown in each pot and seedlings were thinned to three, two weeks after emergence. Two weeks later, another half of $\mathrm{N}$ levels was added to pots. During the course of the experiment, pots were irrigated with distilled water to keep soil moisture content near the field capacity. Plants were harvested after 9 weeks, dried at $65^{\circ} \mathrm{C}$ for $24 \mathrm{~h}$ and weighed. The ground plant samples were dry-ashed at $550{ }^{\circ} \mathrm{C}$ and analyzed for $\mathrm{P}$ by colorimetric method and $\mathrm{Fe}, \mathrm{Mn}, \mathrm{Zn}, \mathrm{Cu}$, $\mathrm{Cd}$, and $\mathrm{Pb}$ by atomic absorption spectrophotometer. Total $\mathrm{N}$ was determined by a micro-Kjeldahl method. At the end of experiment, soil sub-samples were taken from each pot and analyzed for $\mathrm{pH}$ in saturated paste, OM (Jackson 1958), $\mathrm{NO}_{3}-\mathrm{N}$ (Bremner and Keeney 1965), and DTPAextractable $\mathrm{Fe}, \mathrm{Mn}, \mathrm{Zn}, \mathrm{Cu}, \mathrm{Cd}$, and $\mathrm{Pb}$ (Lindsay and Norvell 1978). Furthermore electrical conductivity (ECe), sodium $(\mathrm{Na})$, and chloride $(\mathrm{Cl})$ concentration were

Table 2 Analytical properties of the MWC

\begin{tabular}{|c|c|}
\hline Property & Quantity \\
\hline $\mathrm{EC}\left(\mathrm{dSm}^{-1}\right)$ in $1: 5$ compost:water & 12 \\
\hline pH (1:5 compost:water) & 6.9 \\
\hline pH (1:5 compost:calcium chloride) & 6.7 \\
\hline Total N (\%) & 1.25 \\
\hline $\mathrm{OM}(\%)$ & 18.9 \\
\hline $\mathrm{C}: \mathrm{N}$ & $15: 1$ \\
\hline Total P $\left(\mathrm{mg} \mathrm{kg}^{-1}\right)$ & 810 \\
\hline Total Fe $\left(\mathrm{mg} \mathrm{kg}^{-1}\right)$ & 4175 \\
\hline Total Mn $\left(\mathrm{mg} \mathrm{kg}^{-1}\right)$ & 240 \\
\hline Total $\mathrm{Zn}\left(\mathrm{mg} \mathrm{kg}^{-1}\right)$ & 349 \\
\hline Total $\mathrm{Cu}\left(\mathrm{mg} \mathrm{kg}^{-1}\right)$ & 230 \\
\hline Total $\mathrm{Cd}\left(\mathrm{mg} \mathrm{kg}^{-1}\right)$ & 2.8 \\
\hline Total $\mathrm{Pb}\left(\mathrm{mg} \mathrm{kg}^{-1}\right)$ & 128 \\
\hline \multicolumn{2}{|c|}{ Cations concentration in saturated extract $\left(\mathrm{me} \mathrm{L}^{-1}\right)$} \\
\hline $\mathrm{Ca}^{2+}+\mathrm{Mg}^{2+}$ & 31 \\
\hline $\mathrm{Na}^{+}$ & 54.3 \\
\hline $\mathrm{K}^{+}$ & 59.0 \\
\hline \multicolumn{2}{|c|}{ Anions concentration in saturated extract $\left(\mathrm{me} \mathrm{L}^{-1}\right)$} \\
\hline $\mathrm{HCO}_{3}^{-}+\mathrm{CO}_{3}^{-}$ & 22.3 \\
\hline $\mathrm{SO}_{4}^{2-}$ & 20.0 \\
\hline $\mathrm{Cl}^{-}$ & 56.3 \\
\hline
\end{tabular}

$E C$ electrical conductivity, $O M$ organic matter determined in the saturation extract (U.S. Salinity Laboratory Staff 1954). The data were subjected to statistical analysis of variance (ANOVA) and the Least Significant Difference Test (LSD) was also performed to identify the homogenous sets of data.

\section{Results and discussion}

\section{Growth and mineral composition of tomato plants}

$F$ values and level of significance from ANOVA on studied plant traits are shown in Table 3. A consistent increase in the plant dry matter was observed by raising the levels of the applied MWC (Table 4). This may be due to increase in soil OM, improvement of soil physical and chemical properties and, therefore, better plant nutritional status after MWC usage. Hu and Barker (2004) assessed agriculturalwaste compost, sewage compost and yard waste for their capacity to support tomato growth. Based on vegetative growth, the agricultural-waste compost led to the highest growth while the yard waste caused the least. Generally, increase in nutrient content of the media improved the growth of tomato. In a 3-year study, Maynard (1995) observed that annual additions of MWC significantly increased the yield of field-grown tomato. He indicated that enhancement in soil OM and necessary plant nutrients are responsible for increase in tomato yield.

The effect of applied $\mathrm{N}$ on plant growth was found to be dependent on MWC rate (Table 4). In MWC rates of 0 and $1 \%$, plant dry weight increased as the level of applied $\mathrm{N}$ reached to $50 \mathrm{mg} \mathrm{kg}^{-1}$ soil but further addition of $\mathrm{N}$ reduced the growth of tomato. However, in other MWC rates, plant dry weight was only decreased when applied $\mathrm{N}$ reached $200 \mathrm{mg} \mathrm{kg}^{-1}$ soil. These results show that $\mathrm{N}$ can be more efficient in growth improvement when it is applied in combination with MWC. Although there is no precise explanation for the growth reduction of tomato in the highest level of applied N, it can probably be attributed to ammonium toxicity which resulted from $\mathrm{N}$ volatilization in the alkaline condition of soil under study. Evidences show that among different plant species tomato is highly sensitive to $\mathrm{N}$ volatilization and thus it is used as an index plant for the studies in which the toxicity of ammonium from $\mathrm{N}$ volatilization is evaluated (Adams 1986). Volatilization of $\mathrm{N}$ occurs when large amount of ammonium fertilizers are added to alkaline soils. This process is highly related to soil $\mathrm{pH}$ and is frequently noted in soil $\mathrm{pH}$ higher than 7.5 (Mills et al. 1974; Mattos et al. 2003; Wang et al. 2004). Schuman and Mills (1996) assessed the toxicity caused by ammonium volatilization in buffered sand mediums. Results showed that the most severe injuries in tomato plants occurred when the $\mathrm{pH}$ of medium reached to highest 
Table 3 Analysis of variance (mean square) and $F$ test for studied plant traits

\begin{tabular}{lcclrlllll}
\hline Source of variance & DF & Dry matter & \multicolumn{6}{l}{ Nutrients concentration } \\
\cline { 4 - 9 } & & & $\mathrm{N}$ & $\mathrm{P}$ & $\mathrm{Fe}$ & $\mathrm{Mn}$ & $\mathrm{Zn}$ & $\mathrm{Cu}$ \\
\hline $\mathrm{MWC}$ & 3 & $40.1^{* *}$ & $0.09^{\mathrm{ns}}$ & $383,199^{* *}$ & $67.6^{\mathrm{ns}}$ & $7763^{* *}$ & $4567^{* *}$ & $108^{* *}$ \\
$\mathrm{~N}$ & 3 & $34.4^{* *}$ & $9.7^{* *}$ & $1,750,197^{* *}$ & $148^{\mathrm{ns}}$ & $4074^{* *}$ & $50.9^{*}$ & $0.95^{\mathrm{ns}}$ \\
$\mathrm{MWC} \times \mathrm{N}$ & 9 & $2.36^{\mathrm{ns}}$ & $0.08^{\mathrm{ns}}$ & $1512^{\mathrm{ns}}$ & $164^{\mathrm{ns}}$ & $230^{\mathrm{ns}}$ & $40.5^{*}$ & $3.03^{\mathrm{ns}}$ \\
Error & 32 & 1.69 & 0.08 & 700 & 192 & 313 & 15.7 & 4.05 \\
\hline
\end{tabular}

$*, * *$ and ${ }^{\mathrm{ns}}$ are significant at $5,1 \%$ probability level and non-significant, respectively
Table 4 Effect of MWC and N application on plant dry matter, $\mathrm{N}$ and $\mathrm{P}$ concentration in tomato shoot

\begin{tabular}{|c|c|c|c|c|c|}
\hline \multirow[t]{2}{*}{ MWC rates $(\%)$} & \multicolumn{4}{|c|}{ Applied N (mg kg ${ }^{-1}$ soil) } & \multirow[t]{2}{*}{ Mear } \\
\hline & 0 & 50 & 100 & 200 & \\
\hline \multicolumn{6}{|c|}{ Dry matter $\left(\mathrm{g} \mathrm{pot}^{-1}\right)$} \\
\hline 0 & 5.41 & 9.92 & 7.31 & 5.86 & 7.12 \\
\hline 1 & 6.91 & 11.4 & 10.5 & 8.00 & 9.19 \\
\hline 2 & 8.47 & 11.9 & 12.3 & 9.99 & 10.7 \\
\hline 4 & 10.6 & 11.6 & 13.07 & 9.57 & 11.2 \\
\hline Mean & 7.84 & 11.2 & 10.8 & 8.35 & \\
\hline LSD 0.05 & \multicolumn{2}{|c|}{ Main effects: 0.99} & \multicolumn{2}{|c|}{ Interactions: 1.98} & \\
\hline \multicolumn{6}{|c|}{$\mathrm{N}$ concentration $(\%)$} \\
\hline 0 & 0.93 & 1.51 & 2.87 & 2.77 & 2.02 \\
\hline 1 & 0.92 & 1.55 & 2.53 & 3.16 & 2.04 \\
\hline 2 & 1.07 & 1.66 & 2.46 & 3.01 & 2.05 \\
\hline 4 & 1.26 & 1.85 & 2.64 & 3.1 & 2.21 \\
\hline Mean & 1.26 & 1.85 & 2.64 & 3.10 & \\
\hline LSD 0.05 & \multicolumn{2}{|c|}{ Main effects: 0.19} & \multicolumn{2}{|c|}{ Interactions: 0.38} & \\
\hline \multicolumn{6}{|c|}{$\mathrm{P}$ concentration $\left(\mathrm{mg} \mathrm{kg}^{-1}\right)$} \\
\hline 0 & 3092 & 1817 & 2050 & 1804 & 2191 \\
\hline 1 & 2575 & 1529 & 1458 & 1842 & 1851 \\
\hline 2 & 2175 & 1667 & 1533 & 1750 & 1782 \\
\hline 4 & 2200 & 1850 & 1833 & 1933 & 1954 \\
\hline Mean & 2512 & 1716 & 1719 & 1832 & \\
\hline LSD 0.05 & \multicolumn{2}{|c|}{ Main effects: 194} & \multicolumn{2}{|c|}{ Interactions: 388} & \\
\hline
\end{tabular}

amount of $\mathrm{pH}$ (8.6). Since the soil under study was calcareous in nature, $\mathrm{N}$ volatilization under such circumstances was not unexpected.

Additions of $\mathrm{N}$ to the soil increased $\mathrm{N}$ concentration in plant shoot (Table 4). Although at all levels of the applied $\mathrm{N}$, the effect of MWC on shoot $\mathrm{N}$ concentrations was not significant (Table 4), enhancement in MWC additions increased $\mathrm{N}$ uptake by tomato plant from 140 to $246 \mathrm{mg}$ per pot (nutrients uptake data have not been shown but can be calculated using nutrients concentration and plant dry weight). This can probably be attributed to low $\mathrm{C}: \mathrm{N}$ ratio of MWC. Applied MWC had a suitable C:N ratio (15:1) (Table 2) which could lead to the net mineralization of $\mathrm{N}$ in soil. Maftoun et al. (2004) reported that consumption of
MWC and poultry manure with low $\mathrm{C}: \mathrm{N}$ ratios (12.8 and 7.6, respectively) significantly increased the concentration of $\mathrm{N}$ in spinach plants. Similar results were also reported by Lehrsch and Kincaid (2007) in field-grown corn. In contrast to the stated achievements, Giannakis et al. (2014) found an inhibition of plant growth with increasing dose of municipal solid waste compost in greenhouse-grown lettuce and tomato. Growth inhibition was associated with a sharp decrease in soil $\mathrm{NO}_{3}-\mathrm{N}$ content. Their findings provided evidences that $\mathrm{N}$ immobilization and/or decreased $\mathrm{N}$ mineralization were responsible for inhibited growth by constraining $\mathrm{N}$ availability.

Increasing MWC application reduced the concentration of phosphorous (P) in plant shoot (Table 4). Since P uptake was enhanced by MWC additions from 14.9 to $21.7 \mathrm{mg}$ per pot, the decrease in shoot $\mathrm{P}$ concentration can be related to a dilution effect. Successive application of urban waste compost to a calcareous soil increased organic and inorganic P concentrations in soil and caused higher $\mathrm{P}$ uptake by ryegrass and three other horticultural plants (Carbera et al. 1991). Chattopadhyay et al. (1992) indicated that organic acids and mineral phosphorous obtained from compost decomposition can simultaneously increase phosphorous availability in soil. The effect of $\mathrm{N}$ on plant phosphorous was in part similar to the influence of MWC. In general, $\mathrm{N}$ application up to $100 \mathrm{mg} \mathrm{kg}^{-1}$ soil decreased $\mathrm{P}$ concentration in tomato shoot whereas the highest $\mathrm{N}$ rate significantly increased it. Judging on $\mathrm{P}$ uptake data (not showed), the initial reduction in $\mathrm{P}$ concentration can be due to a dilution effect while the final increase can be assigned to growth reduction which resulted from the highest $\mathrm{N}$ level rather than the enhanced $\mathrm{P}$ uptake.

The effect of MWC and N application on $\mathrm{Fe}, \mathrm{Mn}, \mathrm{Zn}$ and $\mathrm{Cu}$ concentration in tomato shoot has been presented in Table 5. Results showed that MWC did not significantly affect shoot $\mathrm{Fe}$ concentration but effectively increased the total uptake of $\mathrm{Fe}$ as the level of MWC reached $4 \%$ in all applied $\mathrm{N}$ levels. Increase of plant $\mathrm{Fe}$ uptake by MWC application may be due to both higher growth of tomato and the production of chelating agents via MWC decomposition. These chelating agents can enhance availability of $\mathrm{Fe}$ and other micronutrients in soil and consequently 
Table 5 Effect of MWC and $\mathrm{N}$ application on $\mathrm{Fe}, \mathrm{Mn}, \mathrm{Cu}$ and $\mathrm{Zn}$ concentration in tomato shoot

\begin{tabular}{lllll}
\hline MWC rates (\%) & \multicolumn{2}{l}{ Applied $\mathrm{N}\left(\mathrm{mg} \mathrm{kg}^{-1}\right.$ soil) } & Mean \\
\cline { 2 - 4 } & 0 & 50 & 100 & 200 \\
\hline
\end{tabular}

\begin{tabular}{lccccc}
\hline Fe concentration $\left(\mathrm{mg} \mathrm{kg}^{-1}\right)$ & & & & \\
0 & 64 & 68 & 60 & 64 & 64 \\
1 & 60 & 62 & 65 & 57 & 61 \\
2 & 59 & 50 & 55 & 75 & 60 \\
4 & 57 & 57 & 72 & 73 & 64 \\
Mean & 60 & 59 & 63 & 67 &
\end{tabular}

LSD $0.05 \quad$ Main effects: 4.6 Interactions: 9.2

Mn concentration $\left(\mathrm{mg} \mathrm{kg}^{-1}\right)$

$\begin{array}{llllll}0 & 84 & 113 & 136 & 143 & 119 \\ 1 & 50 & 60 & 93 & 98 & 75 \\ 2 & 53 & 59 & 74 & 83 & 67 \\ 4 & 52 & 62 & 66 & 77 & 64 \\ \text { Mean } & 59 & 73 & 92 & 100 & \end{array}$

LSD $0.05 \quad$ Main effects: 6.2 Interactions: 12.3

$\mathrm{Cu}$ concentration $\left(\mathrm{mg} \mathrm{kg}^{-1}\right)$

$\begin{array}{llllll}0 & 10 & 8.1 & 9.9 & 8.4 & 9.1 \\ 1 & 11.7 & 11.3 & 11.5 & 12.3 & 11.7 \\ 2 & 12.9 & 13.4 & 13.2 & 14.4 & 13.5 \\ 4 & 14.4 & 17.6 & 16.3 & 16.7 & 16.2 \\ \text { Mean } & 12.3 & 12.6 & 12.7 & 12.9 & \\ \text { LSD } 0.05 & \text { Main effects: } 1.3 & \text { Interactions: } 2.6 & \end{array}$

LSD $0.05 \quad$ Main effects: $1.3 \quad$ Interactions: 2.6

$\mathrm{Zn}$ concentration $\left(\mathrm{mg} \mathrm{kg}^{-1}\right)$

\begin{tabular}{llllll}
0 & 17 & 11 & 13 & 13 & 13 \\
1 & 27 & 25 & 30 & 28 & 27 \\
2 & 32 & 38 & 38 & 41 & 37 \\
4 & 51 & 62 & 65 & 62 & 60 \\
Mean & 32 & 34 & 36 & 36 & \\
LSD 0.05 & Main effects: 3.4 & Interactions: 6.7 & \\
\hline
\end{tabular}

improve their uptake by plant. Paulrage and Ramulu (1994) indicated that application of $20 \mathrm{tha}^{-1}$ of urban sewage sludge to a sandy-clay soil enhanced the DTPA-extractable $\mathrm{Fe}, \mathrm{Mn}, \mathrm{Zn}$, and $\mathrm{Cu}$ in the soil and also improved their total uptake by tomato plants. Even though the effect of $\mathrm{N}$ application on shoot $\mathrm{Fe}$ concentration was not significant, the mean total uptake of Fe increased by $46 \%$ when the level of applied $\mathrm{N}$ reached $100 \mathrm{mg} \mathrm{kg}^{-1}$ soil. Addition of $200 \mathrm{mg} \mathrm{N} \mathrm{kg}^{-1}$ soil decreased Fe uptake by tomato mainly due to the reduction of dry weight production in this treatment. In general, the increasing effect of MWC on total Fe uptake was more pronounced due to $\mathrm{N}$ addition. Ranjkesh (2015) reported that co-consuming of $\mathrm{N}$ fertilizer and compost accelerated the plant uptake of Fe by two different cultivars of wheat. Mean Mn concentration in the tomato aerial part significantly decreased with increasing MWC rates. Since MWC had no significant effect on total Mn uptake by tomato (it changed from 839 to $715 \mu \mathrm{g}$ per pot which was not significant), the reduction in Mn concentration may be due to dilution effect. Increase of $\mathrm{N}$ levels from 0 to $200 \mathrm{mg} \mathrm{kg}^{-1}$ soil increased mean $\mathrm{Mn}$ concentration by $69 \%$ in tomato shoot (Table 4). Macfie and Taylor (1989) stated that ammonium-bearing fertilizers can increase Mn uptake by plants especially due to reduction of soil $\mathrm{pH}$. In another study (Goldberg et al. 1983), the influence of $\mathrm{N}$ on the enhancement of $\mathrm{Mn}$ concentration in barley shoot was attributed to the dissolution of insoluble Mn by chemical compounds secreted by roots and also to the stimulation of root growth and better contact with soil. Soil application of MWC notably raised mean $\mathrm{Cu}$ concentration in tomato shoot (Table 5). As the level of MWC changed from 0 to $4 \%$ mean, $\mathrm{Cu}$ concentration and its total uptake increased by 78 and $184 \%$, respectively. In spite of the fact that $\mathrm{N}$ application had no significant effect on $\mathrm{Cu}$ concentration (Table 5), $\mathrm{Cu}$ total uptake was significantly affected by $\mathrm{N}$ application. The highest $\mathrm{Cu}$ uptake was observed in $50 \mathrm{mg} \mathrm{N} \mathrm{kg}^{-1}$ soil but there was no significant difference between 50 and $100 \mathrm{mg} \mathrm{N} \mathrm{kg}{ }^{-1}$ soil. Singh and Swarup (1982) studied the copper nutrition of wheat in relation to nitrogen and phosphorous fertilization. The effect of nitrogen on the enhancement of $\mathrm{Cu}$ uptake was attributed to the reduction of soil $\mathrm{pH}$, increase in $\mathrm{Cu}$ solubility, enhancement in root volume and development and finally root secretion of chelating agents with the capacity to increase $\mathrm{Cu}$ availability in soil. MWC had the most significant influence on $\mathrm{Zn}$ concentration in tomato shoot and also the associated uptake of this element by plant. Mean $\mathrm{Zn}$ concentration and total uptake were, respectively, increased by 362 and $638 \%$ as the level of MWC changed from 0 to $4 \%$. This suggests that the availability of $\mathrm{Zn}$ in MWC was the highest in comparison with the other micronutrients including $\mathrm{Fe}, \mathrm{Mn}$, and $\mathrm{Cu}$. On the other hand, MWC contains soluble forms of $\mathrm{Zn}$ which remains bioavailable in the soil and consequently leads to considerable uptake of $\mathrm{Zn}$ by plant. It has been demonstrated (Han and Banin 1999; Kabata-Pendias and Pendias 2001) that metal's nature is a key factor affecting metal speciation and plant bioavailability in soil. For instance, addition of similar amounts of trace elements to soil may cause their different uptake by plant. In fact, the plant bioavailability of each trace element depends on its reaction with various soil components and the chemical behavior of that element in soil. Rajaie et al. (2008) reported that different distribution behavior of $\mathrm{Cd}$ and $\mathrm{Ni}$ in similar circumstances in different soils is partly related to their nature. Therefore, in the present study, the higher bioavailability of $\mathrm{Zn}$ for tomato plant can be also due to its special chemical behavior in the soil. 
Raising $\mathrm{N}$ application from 0 to $200 \mathrm{mg} \mathrm{kg}^{-1}$ soil increased mean $\mathrm{Zn}$ concentration by $12.5 \%$ in tomato shoot (Table 5). The addition of $\mathrm{N}$ up to $100 \mathrm{mg} \mathrm{kg}^{-1}$ soil also increased total $\mathrm{Zn}$ uptake by $57 \%$. Further increase in $\mathrm{N}$ application reduced $\mathrm{Zn}$ uptake by plant. The effect of MWC on plant concentration and uptake of $\mathrm{Zn}$ was dependent on the level of applied N. For instance, in the absence of $\mathrm{MWC}$, increase in $\mathrm{N}$ application from 0 to $200 \mathrm{mg} \mathrm{kg}^{-1}$ soil reduced $\mathrm{Zn}$ concentration and its total uptake by plant. In contrast to $4 \%$ of MWC, the same enhancement in $\mathrm{N}$ level significantly increased the plant responses just mentioned.

In all plant samples, the concentration of $\mathrm{Cd}$ and $\mathrm{Pb}$ were under the detection limit of atomic absorption spectrophotometer. This can be due to low concentration of these elements in MWC (Table 2) and the high $\mathrm{pH}$ and retention capacity of the calcareous soil under study. Rajaie et al. (2006) evaluated the chemical forms of cadmium in two calcareous soil textural classes as affected by application of cadmium-enriched compost and incubation time. Results showed that large proportion of added $\mathrm{Cd}$ was converted to carbonate fraction and approximately stayed the same throughout the course of the experiment. Dixon et al. (1995) showed that the concentration of $\mathrm{Pb}$ and $\mathrm{Cd}$ in spinach plant grown on a compost-enriched soil decreased and/or was unaffected by compost treatments. They believed that this might be due to an increase in soil $\mathrm{pH}$ following the compost addition, low $\mathrm{Pb}$ and $\mathrm{Cd}$ concentration in the material and strong metal-binding capacity of the biosolid.

\section{Chemical properties of the soil}

$F$ values and level of significance from ANOVA on soil chemical properties are shown in Table 6. Soil $\mathrm{pH}$ did not show any significant change with both $\mathrm{MWC}$ and $\mathrm{N}$ application (data no shown). This can be attributed to high CCE (calcium carbonate equivalent) and considerable buffering capacity of the soil under study. In addition, in all soil samples, DTPA-extractable $\mathrm{Cd}$ and $\mathrm{Pb}$ were under the detection limit of atomic absorption spectrophotometer. In control treatments, DTPA-extractable $\mathrm{Fe}, \mathrm{Mn}, \mathrm{Zn}$ and $\mathrm{Cu}$ were higher as compared to the beginning status of the soil (Tables 1, 7). Although there is no precise explanation for this event, it may be attributed to plant exudates secreted by roots in treatments suffered from trace elements deficiency which can lead to increase of these elements availability in the soil. This hypothesis is consistent with the findings reported by Lopez-Millan et al. (2009) in tomato. Except soil $\mathrm{NO}_{3}^{-}$concentration which showed a significant decrease with MWC application; other selected soil chemical characteristics were markedly increased as the level of MWC reached 4\% (Tables 7, 8). For instance, as compared with control, mean values of OM, DTPAextractable $\mathrm{Fe}, \mathrm{Mn}, \mathrm{Zn}, \mathrm{Cu}$, Ece, $\mathrm{Na}$, and $\mathrm{Cl}$ concentration in soil were, respectively, increased by $64,84,47,388$, $100,970,321$, and $662 \%$ in the highest rate of MWC application (Tables 7, 8). The observed change in soil chemical characteristics is consistent with results reported by others (Bevacqua and Mellano 1994; Khoshgoftarmanesh and Kalbasi 2002; Maftoun et al. 2004). The influence of $\mathrm{N}$ fertilization was only significant for soil salinity and the concentration of $\mathrm{NO}_{3}^{-}$and $\mathrm{Cl}$ in the soil (Tables 6, 8). Generally, the soil chemical properties just mentioned were significantly enhanced with increments in $\mathrm{N}$ addition (Table 8). In the present study, the enhancing effect of $\mathrm{N}$ on soil salinity was more pronounced in the absence of MWC. For instance, without MWC application, addition of $200 \mathrm{mg} \mathrm{N} \mathrm{kg}^{-1}$ soil increased ECe by $434 \%$ when compared to control, whereas with $4 \%$ of MWC and the same $\mathrm{N}$ rate, the increase was only $32 \%$ (Table 8 ). This observation can be attributed to the improved growth of tomato associated with increments in MWC addition. On the other hand, greater growth of tomato led to higher absorption of $\mathrm{NO}_{3}^{-}$and other existent elements which in consequence made a reduction in soil salinity. Despite the fact that tomato is moderately sensitive to salt stress, no adverse effect on plant growth was observed with the increase in soil salinity (Tables 4,8 ). The apparent tolerance of this crop to salinity in our study may be due to

Table 6 Analysis of variance (mean square) and $F$ test for soil chemical properties

\begin{tabular}{|c|c|c|c|c|c|c|c|c|c|c|}
\hline \multirow[t]{2}{*}{ Source of variance } & \multirow[t]{2}{*}{ DF } & \multirow[t]{2}{*}{$\mathrm{OM}$} & \multirow[t]{2}{*}{$\mathrm{Na}$} & \multicolumn{4}{|c|}{ DTPA-extractable trace elements } & \multirow[t]{2}{*}{$\mathrm{EC}$} & \multirow[t]{2}{*}{$\mathrm{NO}_{3}$} & \multirow[t]{2}{*}{$\mathrm{Cl}$} \\
\hline & & & & $\mathrm{Fe}$ & Mn & $\mathrm{Zn}$ & $\mathrm{Cu}$ & & & \\
\hline MWC & 3 & $0.87 * *$ & $107 * *$ & $29.3 * *$ & $41 * *$ & $97 * *$ & $6.73 * *$ & $18.0^{* *}$ & $362 * *$ & $240 * *$ \\
\hline $\mathrm{N}$ & 3 & $0.01^{\mathrm{ns}}$ & $0.17^{\mathrm{ns}}$ & $0.38^{\mathrm{ns}}$ & $3.6^{\mathrm{ns}}$ & $0.80^{\mathrm{ns}}$ & $0.018^{\mathrm{ns}}$ & $4.26 * *$ & $22,863 * *$ & $13.2 * *$ \\
\hline $\mathrm{MWC} \times \mathrm{N}$ & 9 & $0.01^{\mathrm{ns}}$ & $0.34^{\mathrm{ns}}$ & $0.29^{\mathrm{ns}}$ & $1.31^{\mathrm{ns}}$ & $0.35^{\mathrm{ns}}$ & $0.007^{\mathrm{ns}}$ & $0.011 * *$ & $165^{*}$ & $4.11 * *$ \\
\hline Error & 32 & 0.01 & 0.28 & 0.56 & 1.73 & 0.52 & 0.008 & 0.007 & 59 & 0.75 \\
\hline
\end{tabular}

$*, * *$ and ${ }^{\mathrm{ns}}$ are significant at $5,1 \%$ probability level and non-significant, respectively 
Table 7 Effect of MWC on some soil properties including soil organic matter (OM) and concentration of $\mathrm{Na}, \mathrm{Fe}, \mathrm{Mn}, \mathrm{Zn}$, and $\mathrm{Cu}$ (each figure is the mean of 12 observations)

\begin{tabular}{llllll}
\hline MWC rates $(\%)$ & $\mathrm{OM}(\%)$ & $\mathrm{Na}\left(\mathrm{me} \mathrm{L}^{-1}\right)$ in saturated paste & \multicolumn{3}{l}{ DTPA-extractable trace elements $\left(\mathrm{mg} \mathrm{kg}^{-1}\right)$} \\
\cline { 4 - 6 } & & & $\mathrm{Fe}$ & $\mathrm{Mn}$ & $\mathrm{Zn}$ \\
\hline 0 & 1.01 & 0.71 & 4.4 & 5.1 & 1.22 \\
1 & 1.21 & 2.1 & 5.5 & 10.0 & 2.48 \\
2 & 1.30 & 3.9 & 6.2 & 10.9 & 4.03 \\
4 & 1.66 & 7.6 & 8.1 & 13.4 & 5.96 \\
LSD 0.05 & 0.14 & 0.42 & 0.79 & 1.5 & 0.50 \\
\hline
\end{tabular}

Table 8 Effect of MWC and $\mathrm{N}$ application on soil salinity and concentration of $\mathrm{NO}_{3}^{-}$and $\mathrm{Cl}$ in the soil

\begin{tabular}{|c|c|c|c|c|c|}
\hline \multirow[t]{2}{*}{ MWC rates $(\%)$} & \multicolumn{4}{|c|}{ Applied $\mathrm{N}$ (mg kg ${ }^{-1}$ soil) } & \multirow[t]{2}{*}{ Mean } \\
\hline & 0 & 50 & 100 & 200 & \\
\hline \multicolumn{6}{|l|}{$\mathrm{EC}\left(\mathrm{dSm}^{-1}\right)$} \\
\hline 0 & 0.35 & 0.46 & 0.79 & 1.87 & 0.87 \\
\hline 1 & 0.97 & 1.32 & 1.42 & 2.78 & 1.63 \\
\hline 2 & 2.13 & 2.53 & 2.48 & 3.23 & 2.60 \\
\hline 4 & 3.27 & 3.47 & 3.73 & 4.32 & 3.67 \\
\hline Mean & 1.62 & 1.94 & 2.11 & 3.05 & \\
\hline LSD 0.05 & \multicolumn{2}{|c|}{ Main effects: 0.23} & \multicolumn{2}{|c|}{ Interactions: 0.47} & \\
\hline \multicolumn{6}{|l|}{$\mathrm{NO}_{3}\left(\mathrm{mg} \mathrm{kg}^{-1}\right)$} \\
\hline 0 & 5 & 3 & 21 & 115 & 36 \\
\hline 1 & 4 & 5 & 10 & 92 & 28 \\
\hline 2 & 6 & 3 & 6 & 79 & 23 \\
\hline 4 & 5 & 5 & 7 & 89 & 26 \\
\hline Mean & 5 & 4 & 11 & 94 & \\
\hline LSD 0.05 & \multicolumn{2}{|c|}{ Main effects: 3.9} & \multicolumn{2}{|c|}{ Interactions: 7.8} & \\
\hline \multicolumn{6}{|c|}{$\mathrm{Cl}\left(\mathrm{me} \mathrm{L}^{-1}\right)$ in saturated paste } \\
\hline 0 & 1.6 & 1.6 & 1.7 & 1.7 & 1.6 \\
\hline 1 & 3.5 & 4.2 & 4.5 & 6.9 & 4.8 \\
\hline 2 & 6.2 & 8.5 & 8.3 & 7.5 & 7.6 \\
\hline 4 & 9.2 & 13.7 & 11.5 & 14.2 & 12.2 \\
\hline Mean & 5.1 & 7.0 & 6.5 & 7.6 & \\
\hline LSD 0.05 & \multicolumn{2}{|c|}{ Main effects: 0.62} & \multicolumn{2}{|c|}{ Interactions: 1.23} & \\
\hline
\end{tabular}

applied variety and also the fact that the salinity effects might have been alleviated by the constant and adequate supply of water in the controlled environment. Papadopoulos and Rendig (1983) reported that even at high salinity level plant growth could still occur if enough moisture is supplied.

Although $\mathrm{N}$ fertilization obviously increased mean $\mathrm{Cl}$ concentration in soil saturated paste, the increasing effect of $\mathrm{N}$ was MWC rate dependent (Table 8). For instance, in the absence of MWC, application of $200 \mathrm{mg} \mathrm{N} \mathrm{kg}^{-1}$ increased $\mathrm{Cl}$ concentration only by $6 \%$ when compared to control, whereas with $4 \%$ of MWC and the same $\mathrm{N}$ rate the increase was 54\% (Table 8). As it was reported by Irshad et al. (2002) and Tabatabaei (2006), the increasing effect of $\mathrm{N}$ on $\mathrm{Cl}$ concentration in soil saturated paste can be attributed to anionic competition and restricting effect of $\mathrm{NO}_{3}^{-}$on $\mathrm{Cl}^{-}$uptake by plant.

\section{Conclusions}

Results of this study indicate that the combined use of MWC and $\mathrm{N}$ fertilizer can improve the growth and chemical composition of tomato. However, their rates of application for each crop needs to be evaluated under field conditions. The major concerns for the use of organic wastes in agricultural soils are the hazards of heavy metals accumulation and the elevated levels of soluble salts in crop root zone. Commonly the metals of concern are $\mathrm{Cd}, \mathrm{Pb}, \mathrm{Zn}$, and $\mathrm{Cu}$. Although $\mathrm{MWC}$ had noticeable concentration of $\mathrm{Pb}, \mathrm{Cu}$, and $\mathrm{Zn}$, it had no deleterious effect on tomato growth. As a matter of fact, the soil used in this experiment had high $\mathrm{pH}$ and CCE values and contained a large amount of clay minerals which in turn could immobilize heavy metals in the soil. Therefore, MWC had no hazardous effect on plant growth but also played a nutritional role in the case of nutrient metals such as $\mathrm{Zn}$ and $\mathrm{Cu}$. Although nitrogen enhanced the concentration and/or plant uptake of cationic micronutrients, the concentration of these elements did not reach to toxic levels. A rise in ECe following addition of high levels of organic wastes to soil suggests that with continued application, total soluble salts may reach toxic levels for some crops especially under arid and semi-arid conditions of Iran. Therefore, there is a clear and urgent need to monitor soluble salt levels when making repeated application of organic wastes in calcareous soils of Iran over an extended period of time.

Acknowledgements Funding was provided by Agricultural Research, Education and Extension Organization, Tehran, Iran 
Open Access This article is distributed under the terms of the Creative Commons Attribution 4.0 International License (http://crea tivecommons.org/licenses/by/4.0/), which permits unrestricted use, distribution, and reproduction in any medium, provided you give appropriate credit to the original author(s) and the source, provide a link to the Creative Commons license, and indicate if changes were made.

\section{References}

Adams P (1986) Mineral nutrition. In: Atherton JG, Rudish J (eds) The tomato crop. Chapman and Hall Ltd, New York

Amusan AO, Adetunji MT, Azeez JO, Bodunde JG (2011) Effect of the integrated use of legume residue, poultry manure and inorganic fertilizers on maize yield, nutrient uptake and soil properties. Nutr Cycl Agroecosyst 90(3):321-330

Basta NT, Tabatabai MA (1992) Effect of cropping systems on adsorption of metals by soils: II. Effect of $\mathrm{pH}$. Soil Sci 153:195-204

Bertoldi M, Sequi P, Lemmens B, Papi T (eds) (1996) The science of composting, Part 1, 1st edn. Blakie Academic and Professional, Glasgow

Bevacqua RF, Mellano VJ (1994) Cumulative effects of sludge compost on crop yields and soil properties. Commun Soil Sci Plant Anal 25:395-406

Bingham FT, Page AL, Mitchell GA, Strong JE (1979) Effects of liming an acid soil amended with sewage sludge enriched with $\mathrm{Cd}, \mathrm{Cu}, \mathrm{Ni}$, and $\mathrm{Zn}$ on yield and $\mathrm{Cd}$ content of wheat grain. J Environ Qual 8:202-207

Bremner JM, Keeney DR (1965) Steam distillation method for determination of ammonium and nitrate. Anal Chim Acta 32:485-495

Carbera F, Murillo JM, Lopez R, Hernandez JM (1991) Fate of phosphorous added with urban compost to a calcareous soil. J Environ Sci Health B 29:83-97

Cela S, Santiveri F, Loveras J (2011) Residual effects of pig slurry and mineral nitrogen fertilizer on irrigated wheat. Eur J Agron 34(4):257-262

Chattopadhyay N, Gupta MD, Gupta SK (1992) Effect of city compost and fertilizers on the growth, nutrient uptake and yield of rice. J Indian Soc Soil Sci 40:464-468

Chivenge P, Vanlauwe B, Six J (2011) Does the combined application of organic and mineral nutrient sources influence maize productivity? A meta-analysis. Plant Soil 342(1-2):1-30

Demelash N, Bayu W, Tesfaye S, Ziadat F, Sommer R (2014) Current and residual effects of compost and inorganic fertilizer on wheat and soil chemical properties. Nutr $\mathrm{Cycl}$ Agroecosyst 100(3):357-367

Dixon FM, Preer JR, Abdi AN (1995) Metal levels in garden vegetables raised on biosolid amended soil. Compost Sci Util 3:55-63

Eriksson JE (1989) The influence of $\mathrm{pH}$, soil type and time on adsorption and uptake by plants of $\mathrm{Cd}$ added to the soil. Water Air Soil Pollut 48:317-335

Eriksson JE (1990) Effects of nitrogen-containing fertilizers on solubility and plant uptake of cadmium. Water Air Soil Pollut 49:355-368

Giannakis GV, Kourgialas NN, Paranychianakis NV, Nikolaidis NP, Kalogerakis N (2014) Effects of municipal solid waste compost on soil properties and vegetables growth. Compost Sci Util 22(3):116-131

Goldberg SP, Smith KA, Holmes JC (1983) The effect of soil compaction, forms of nitrogen, and fertilizers placement on the availability of manganese to barley. J Sci Food Agric 34:657-670

Han FX, Banin A (1999) Long-term transformation and redistribution of potentially toxic heavy metals in arid-zone soils: incubation in field capacity content. Water Air Soil Pollut 114:221-250

Hashemimajd K, Kalbasi M, Golchin A, Shariatmadari H (2004) Comparison of vermicompost and composts as potting media for growth of tomatoes. J Plant Nutr 27(6):1107-1123

Havaee S, Ayoubi S, Mosaddeghi MR, Keller T (2014) Impacts of land use on soil organic matter and degree of compactness in Calcareous soils of Central Iran. Soil Use Manag 30:2-9

$\mathrm{Hu}$ Y, Barker AV (2004) Evaluation of composts and their combinations with other materials on tomato growth. Commun Soil Sci Plant Anal 35:2789-2807

Irshad M, Honna T, Eneji AE, Yamamoto S (2002) Wheat response to nitrogen source under saline conditions. J Plant Nutr 25:2603-2612

Jackson ML (1958) Soil chemical analysis. Prentice Hall, Englewood Cliffs

Kabata-Pendias A, Pendias H (2001) Trace elements in soils and plants, 3rd edn. CRC Press, Boca Raton

Kabirinejad S, Hoodaji M (2012) The effects of biosolid application on soil chemical properties and Zea mays nutrition. Int J Recycl Organic Waste Agric 1:4

Karimian N, Ahangar G (1998) Manganese retention by selected calcareous soils as related to soil properties. Commun Soil Sci Plant Anal 29:1061-1070

Khoshgoftarmanesh AK, Kalbasi M (2002) Effect of municipal waste leachate on soil properties and growth and yield of rice. Commun Soil Sci Plant Anal 33:2011-2020

Lehrsch GA, Kincaid DC (2007) Compost and manure effects on fertilized corn silage yield and nitrogen uptake under irrigation. Commun Soil Sci Plant Anal 38(15):2131-2147

Lindsay WL, Norvell WA (1978) Development of a DTPA test for zinc, iron, manganese, and copper. Soil Sci Soc Am J 42:421-428

Lopez-Millan AF, Morales F, Gogorcena Y, Abadia A, Abadia J (2009) Metabolic responses in iron deficient tomato plants. J Plant Physiol 166:375-384

Macfie SM, Taylor GJ (1989) The effect of $\mathrm{pH}$ and ammonium on the distribution of manganese in triticum aestivum grown in solution culture. Can J Bot 67:3394-3400

Maftoun M, Moshiri F, Karimian N, Ronaghi AM (2004) Effects of two organic wastes in combination with phosphorus on growth and chemical composition of spinach and soil properties. J Plant Nutr 27(9):1635-1651

Mattos D Jr, Alva AK, Paramasivam S, Graetz DA (2003) Nitrogen volatilization and mineralization in a sandy entisol of Florida under citrus. Commun Soil Sci Plant Anal 34(13):1803-1824

Maynard A (1995) Cumulative effect of annual additions of MWC compost on the yield of field-grown tomatoes. Compost Sci Util 3:55-63

McGrath SP, Sanders JR, Shalaby MH (1988) The effects of soil organic matter levels on soil solution concentration and extractabilities of manganese, zinc and copper. Geoderma 42:177-188

Mills HA, Baker AV, Maynard DN (1974) Ammonium volatilization from soils. Agron J 66:355-358

Ohtani T, Kawabata M, Sase A, Fukami M (2007) Cadmium and nutrient heavy metals uptake by rice, barley, and spinach as affected by four ammonium salts. J Plant Nutr 30:599-610

Papadopoulos I, Rendig VV (1983) Tomato plant response to soil salinity. Agron J 75:696-700

Parvizi Y, Ronaghi A, Maftoun M, Karimian NA (2004) Growth, nutrient status, and chlorophyll meter readings in wheat as 
affected by nitrogen and manganese. Commun Soil Sci Plant Anal 35:1387-1399

Paulrage C, Ramulu US (1994) Effect of soil application of low levels of urban sewage sludge on the uptake of nutrients and yield of certain vegetables. J Indian Soc Soil Sci 42:485-487

Petruzzelli G (1996) Heavy metals in compost and their effect on soil quality. In: Bertodi M, Sequi P, Lemmes B, Papi T (eds) The science of composting, part 1, 1st edn. Blakie Academic and Professional, Glasgow, pp 213-223

Rajaie M, Karimian N, Maftoun M, Yasrebi J, Assad MT (2006) Chemical forms of cadmium in two calcareous soil textural classes as affected by application of cadmium-enriched compost and incubation time. Geoderma 136:533-541

Rajaie M, Karimian N, Yasrebi J (2008) Nickel transformation in two calcareous soil textural classes as affected by applied nickel sulfate. Geoderma 144:344-351

Ranjkesh M (2015) Evaluation of organic and chemical fertilizers effects on iron absorption at Cultivars of Darya and N8019 Wheat. Int J Farming Allied Sci 4(1):61-65

Rodriguez-Ortiz JC, Valdez-Cepeda RD, Lara-Mireles JL, RodriguezFuentes H, Vazquez-Alvarado RE, Magallanes-Quintanar R, Garcia-Hernandez JL (2006) Soil nitrogen fertilization effects on phytoextraction of cadmium and lead by tobacco (Nicotiana tabacum L.). Bioremediat J 10(3):105-114
Schuman AW, Mills HA (1996) Injury of leatherleaf fern and tomato from volatilized ammonia after fertilizer application. J Plant Nutr 19:573-593

Singh DV, Swarup C (1982) Copper nutrition of wheat in relation to nitrogen and phosphorous fertilization. Plant Soil 65:433-436

Sohrabi Yourtchi M, Haj Seyyed Hadi MR, Darzi MT (2013) Effect of nitrogen fertilizer and vermicompost on vegetative growth, yield and NPK uptake by tuber of potato (Agria CV.). Int J Agric Crop Sci 5(18):2033-2040

Tabatabaei SJ (2006) Effects of salinity and $\mathrm{N}$ on the growth, photosynthesis and $\mathrm{N}$ status of olive (Olea europaea L.) trees. Sci Hortic 108:432-438

U.S. Salinity Laboratory Staff (1954) Diagnosis and improvement of saline and alkali soils, USDA Handbook No. 60. Government Printing Office, U.S., Washington DC

Wang ZH, Liu XJ, Ju XT, Zhang FS, Malhi SS (2004) Ammonia volatilization loss from surface-broadcast urea: comparison of vented- and closed-chamber methods and loss in winter wheatsummer maize rotation in north china plain. Commun Soil Sci Plant Anal 35(19):2917-2939

Zinati GM, Li YC, Bryan HH, Mylavarapu RS, Cadallo M (2004) Distribution and fractionation of phosphorus, cadmium, nickel, and lead in calcareous soils amended with composts. J Environ Sci Health B 39(1):209-223 